The International Journal of
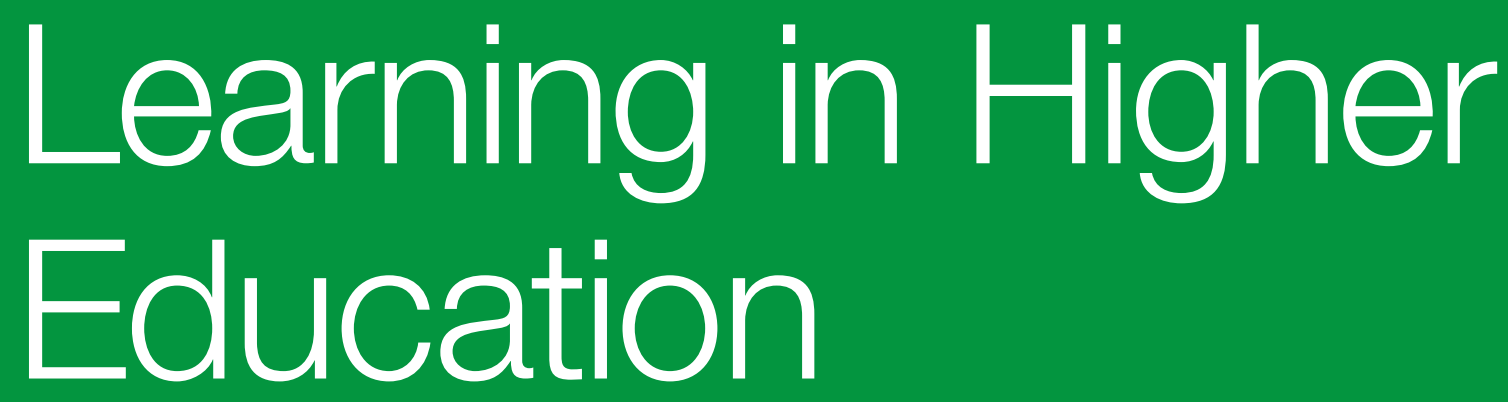

An Attempt to Design a Business Capstone Course

\title{
A Personal Experience
}

THEODORA ISSA 
THE INTERNATIONAL JOURNAL OF LEARNING IN HIGHER EDUCATION

http://thelearner.com/

First published in 2013 in Champaign, Illinois, USA

by Common Ground Publishing

University of Illinois Research Park

2001 South First St, Suite 202

Champaign, IL 61820 USA

www.CommonGroundPublishing.com

ISSN: 2327-7955

(C) 2013 (individual papers), the author(s)

(C) 2013 (selection and editorial matter) Common Ground

All rights reserved. Apart from fair dealing for the purposes of study, research, criticism or review as permitted under the applicable copyright legislation, no part of this work may be reproduced by any process without written permission from the publisher. For permissions and other inquiries, please contact <cg-support@commongroundpublishing.com>.

The International Journal of Learning in Higher Education is a peer-reviewed scholarly journal.

Typeset in CGScholar.

http://www.commongroundpublishing.com/software/ 


\title{
An Attempt to Design a Business Capstone Course: A Personal Experience
}

\author{
Theodora Issa, Curtin University, Australia
}

\begin{abstract}
Derived from a personal experience, this paper presents a framework on how a 'Capstone Course' might be developed at a university in Australia. This paper begins with a selective literature review on the diverse ideas and methods of teaching a 'Capstone Course' at different levels and disciplines, then discusses the process followed to have the course syllabus and outcomes approved by top management. The literature will shed some light on the ways by which this course is delivered at business schools in different parts of the world at various levels. A common theme in the literature is that, regardless of the diverse ways in which this course can be delivered, the syllabus must be relevant to real-life situations and actual business practices. This is a difficult task since differences are apparent regarding the contents of this course and the diverse views regarding the sort of relationship that a university should have with businesses. Indeed, in obtaining necessary approvals as to how this course can be delivered, there are both challenges and limitations. This paper reports on a personal experience in developing such a course, highlighting the great opportunities and the immense challenges faced by the developer. This paper shares with readers a 'theoretical' vision rather than a 'practical' implementation of a Capstone Course designed for inter-disciplinary business students in Australia. This paper highlights the challenges and limitations experienced, with suggestions and steps depicted in a conceptual model as to how best a 'Business Capstone' course can be designed and implemented to achieve the ultimate goal of preparing students for the real world.
\end{abstract}

Keywords: Business Schools, Undergraduate Students, Capstone, Academics, Service-Learning, Triple Bottom Line, Ethical and Moral Evaluations, Australia

\section{Introduction}

$\mathrm{I}$ $\mathrm{n}$ the past few years, transgressions and wrongdoings in the business world have provided the catalyst for business schools to question their own pedagogical methods and curriculums. Certainly, the Global Financial Crisis (GFC) has placed Business Schools under immense pressure to develop not only employees but also leaders who embody values and exhibit, without fail, the highest levels of ethical decision-making, social justice, social responsibility, global awareness and professional excellence. Certainly, business schools need to groom their students to face the challenges of the uncertain business world. This is a massive task, especially with the ongoing changes and shifts experienced in the way contemporary businesses are conducted.

There is a higher demand on business schools to shift their students' mindsets to view their role in the business world in a holistic manner, across functional, course and regional boundaries rather than only in relation to the economic and financial outcomes. They need to be able to promote transparency and demonstrate understanding of risks at the social, economic and environmental levels, and mitigate these risks. When developing a 'Capstone Course', business schools understand and consider the need to both exploit and enhance their students' information competency through the application of what they had learned in previous courses in their university programs.

Indeed, there are challenges and limitations associated with the design, implementation and delivery of this course. This paper reports on a personal experience in the design of a Capstone course, highlighting the great opportunities, the immense challenges and limitations that were faced in attempting to develop the course. This paper presents a 'theoretical' vision of how a course such as business Capstone course can be designed, implemented, and delivered to inter-disciplinary business students in Australia.

This paper is organized as follows: a very brief overview and background on the design of Capstone Courses and approaches employed in delivering such course is then followed by a selective literature review. Next, various definitions of the 'Capstone Course' are examined, with

The International Journal of Learning in Higher Education

Volume 19, 2013, thelearner.com, ISSN: 2327-7955

(C) Common Ground, Theodora Issa, All Rights Reserved

Permissions: cg-support@commongroundpublishing.com 
the writer then offering her own definition. This is followed by a review of what is being done in the undergraduate and postgraduate Capstone Courses in diverse disciplines worldwide. The third section discusses the contribution of this paper, presents the methodology, vision, limitations and challenges, and the conceptual model. This paper concludes with a brief section on lessons learned from this personal experience.

\section{Brief Overview and Background of Capstone Course and Approaches Employed}

This section provides a brief overview and background of a Capstone Course. The literature review indicates that several attempts have been made to define, design, develop and implement a Capstone Course from different perspectives, employing diverse approaches, in different areas, disciplines and countries. While all these definitions concentrate on adding to basic knowledge and enhancing communication skills, more recently there have been calls to develop students' skills in critical thinking, moral reasoning, social, reflective abilities and professional attitudes.

A 'Capstone Course' is not a new phenomenon, but has been presented in different formats and under diverse names over the years. Almost two decades ago, Jauch, Snodgrass and Szewczak (1988) contended that in business schools, the 'Capstone Course' had been shifting from 'integrating functional areas' to a 'strategic management' paradigm, with some incorporating simulation games, enhancing emphasis on content of strategy concept and computer literacy. Jauch et al. (1988) argued that these concepts have not been well integrated into extant strategy courses or the simulations used in them, proposing a new 'Capstone Course' based on simulation that integrates all areas, including decision support systems. Cohen, Eimicke and Ukeles (1995) highlighted the need to integrate policy and management in a 'Capstone Course', with Elkington (1997) arguing the case of the triple-bottom line in the twenty-first century. This is only a small sample of literature that highlights different approaches to 'Capstone Courses'. Indeed, diverse course designs at different locations are evident. For example, discussing the results of a comprehensive review of some one hundred twenty-two Capstone marketing syllabi from across the United States, Crittenden and Crittenden (2006) contend that a 'Capstone Course' goes by an extensive listing of course names, a wide variety of textbooks and reading material, with an overarching course objective to provide a better understanding of marketing strategy.

By the same token, Harper, Lamb and Buffington (2000) provided evidence from students over three semesters of their widespread satisfaction with the case study approach in teaching the higher-level concepts in a Capstone Course. However, not all agreed that the Capstone course approach is best. Although a Capstone Course can go by a range of different names (i.e. business policy, business strategy and policy or strategic management), Payne, Whitfield and Flynn (2002) suggested that despite this, in the United States, such courses would involve integrative and strategic learning objectives. Payne et al. (2002) described a theoretical foundation, an inquiry process, and an assessment framework for review and evaluation of such business Capstone Courses. Recently, Starr-Glass (2010) posited that Capstone experience had become ubiquitous in undergraduate education. Posing the question as to whether a Capstone Course serves as capping, bridging or both, Starr-Glass (2010) explored the origin of the Capstone Course, stating that back in the 1970s, Capstone courses served as a terminal display of academic excellence and bridging experience between study and work. However, more recently, this course has been transformed to be seen in terms of academic completion and consolidation. Furthermore, other scholars in the field emphasize the importance of developing a Capstone Course that meets the requirements of the accreditation agencies (e.g. Aurand and Wakefield 2006, Francisco et al. 2008). More recently, and with the uncertain climate in businesses, specifically the hostility facing banks worldwide, some suggested that such a course be built around the recent banking crisis (Razaki et al. 2010).

Besides the fact that a Capstone Course is considered as the climax of student experience in higher education, cultivating their knowledge throughout their university education, this seems 
insufficient; thus, there are those who argue the case for the inclusion of ethics and sustainability in a Capstone Course (e.g. Brabston 2005, Giacalone et al. 2003, Heuer 2010, Razaki and Collier 2011, Whitla 2011). Such opinions are not new to Capstone courses development. However, the idea of incorporating ethics in a holistic course such as a Capstone Course has been assessed. In an examination of accounting students in a Capstone Course who were taught 'business ethics', Shaub (1994) contended that those students who were exposed to and were taught ethics had demonstrated higher levels of moral reasoning than others who did not, concluding that accounting educators can influence the moral reasoning of the profession in different ways, one of which would be by designing an ethics education intervention that is anticipated to help accounting students incorporate more than simply rules in making ethical decisions. This idea is important especially with the transgressions recorded in the accounting profession despite it having the oldest professional code of conduct.

Subsequent to the GFC, Razaki, Koprowski, Alonzi and Irons (2010) underlined the importance of not only accounting, business economics and finance, but rather ethical issues, with Balch and Borah (2010) stressing the importance of skills such as critical thinking and problemsolving for a Capstone Course. Nonetheless, in a further discussion, Razaki and Collier (2011) underscored some of the main weaknesses of ethics education in a concrete approach to developing a business Capstone Course for student areas of accounting and finance, calling for the substitution of the traditional case study method with a community-based service-learning method. To some extent, and as indicated in the literature, this is being achieved through a core course termed a 'Business Capstone Course'. However, it is worthwhile to note here that there is no 'one size fits all', as this course has been offered using diverse methods by various business schools, under a variety of names, in different parts of the world. Nonetheless, no matter how diverse these courses are, in most cases, they aim to relate their students' experience as closely as possible to real life and actual business practices. However, differences are apparent regarding course content and opinions about the nature of the relationship between the university and businesses. Wiechowski (2010) poses the challenge of accommodating not only on-campus students but those online, especially in relation to assessing the competencies relevant to team work and communication skills, including oral presentation skills.

Discussing the changes in teaching models over the past decade that reflect the dynamics, complexities and uncertainties of today's organizations, Reid, Brown and Tabibzadeh (2012) contend that traditional and more current active models of learning are now disadvantaged. In order to meet such a complex environment, and ensure that students are ready to face the challenging and uncertain business world, Reid and colleagues (2012) provide empirical evidence of the usefulness of simulation as a platform to combine the best aspects of different types of teaching practices.

A literature review on 'Capstone Courses' will not be complete without having an insight into educational practice and philosophy. In this respect, service-learning, coined in the late 'sixties, seems to have gained momentum recently when 'Capstone Courses' are discussed. This is because of the complexity of the contemporary business world, and the difficulties faced by students in adapting to the professional requirements of their new work environments. In this respect, Wei and Burley (2006) introduced service-learning to an undergraduate Capstone Courses in information technology and information systems, thus integrating their classroom concepts with the community requirements through the completion of their projects.

Further, not only service-learning but also problem-solving is another key method to prepare students for future careers. Indeed, students in a Capstone Course need to be able to observe an issue, spot the problem, have the ability required to analyse the holistic situation and provide recommendations and solutions. In this regard, Nickerson, Yen, and Mahoney (2012) posit that an emerging problem-finding and problem-solving approach suggests that management's ability to discover problems to solve, opportunities to seize, and challenges to respond to is vital to organizations, and will therefore be important to individuals within organizations. They explore 
the extent to which the problem-finding and problem-solving approach can provide a foundation for combining the capabilities, dynamic capabilities, and governance perspectives as a way to help scholars and practitioners to coherently design organizations from the perspective of design science.

Furthermore, Strauss (2011) puts the problem-solving approach into practice, providing evidence from a marketing Capstone Course that uses cases, simulations, and client-sponsored projects. This involves no exams or grades, but rather, students are at liberty to conduct their work in the way they feel is most appropriate. Indeed, after being exposed to a problem, students need to decide what further information they require in order to assist them to solve the problem with the instructor serving as a coach/facilitator only. Strauss concludes that the problem-solving approach engages and motivates students by providing real-world problems in a short time frame. This serves to develop the students' skills in creative problem solving, presentation, time management, and team work.

The following section considers several definitions of a 'Capstone Course' in order to generate a refined and succinct definition for the purpose of this paper.

\section{Capstone Definitions}

Payne et al. (2002) state that the business Capstone Course, (often known by different names such as Business Policy, Business Strategy and Policy, or Strategic Management in many business schools in the United States) usually involves integrative and strategic learning objectives for students. Whereas, Matos and Grasser (2006) opine that a Capstone Course illustrates the fusion of different (but interdependent) issues and techniques learned by students in their previous Courses. While Ras et al. (2007: p. 312) believe that a Capstone project helps students to increase their problem-solving competencies, improve their social skills (e.g., communication skills), and acquire practical experience. Nonetheless, Murray et al. (2008) highlights the importance of previous courses in higher education program, contending that the Capstone Course experience draws from previous work undertaken by students during their progression of study, with Mills et al. (2008) stating that Capstone represents, in part, a reflection of the effectiveness of the departmental program.

Boehner and O’Neil (2010) bring a new dimension to the definition of a Capstone Course, considering it as a team-based Capstone project that engages external clients, giving students an opportunity for learning and personal growth. While Starr-Glass (2010) regards Capstone experiences as holistic solutions to revitalize undergraduate education, underpinned by broad educational considerations, and with multiple purposes. Whereas, Wiechowski (2010) defines Capstone as a course providing an opportunity to integrate several topics and to help prepare students for the real world, while Strauss (2011) describes it as a course that provides students with a comprehensive application of previously learned concepts. Lewis (2011) believes that Capstone is often the last course students will undertake prior to earning their business degree, so as business educators, it may be the last opportunity we have to reach our students before they enter the working world. Lewis considers that a Capstone Course is likely to play an important role in setting the 'tone' for what it means to be a business professional in today's ever-changing world. Moshkovich (2012) considers that Capstone Courses are necessary to ensure the convergence of all ingredients. However, Kachra and Schnietz (2008) sound an alarm, stating that while a Capstone Course is intended to integrate the prior course work of the program, in fact it is doing this less and less well in today's high-velocity and complex business environment.

Thus, it can be seen that a Capstone Course is important, if not vital, for the success of students at the post- and undergraduate levels. The literature suggests that Capstone Course is a valuable course that can be offered in different disciplines and at both post- and undergraduate levels. Capstone is becoming a standard feature of higher education, offering different pedagogical methods. Although pedagogical methods are important, there is also a need to incorporate within 
these methods a means of developing students' morality and professionalism which are becoming increasingly important skills for both post- and undergraduates. Synthesising these definitions, a Capstone Course developed by this researcher would endeavour to:

'allow students the learning opportunities to integrate basic knowledge of theory, content, that is coupled and intertwined with application and practice, thus enhancing the students' analytical, critical, and professional skills, moral reasoning and reflective practice.'

Without a doubt, the literature provides a tapestry of ideas on what needs to be included, and how such a holistic course, such as 'Capstone Course' needs to be developed and implemented. An investigation of the literature of the past decade yields the following issues or pedagogical plans for a Capstone Course.

\section{Capstone for Undergraduate Courses}

Certainly, a Capstone Course is important, but needs to be pitched at the right level. There are several successful stories of Capstone Courses. However, with the ongoing changes in the business environment, there is a need to always develop and invent better ways to deliver such a crucial course as the Capstone Course, even at the undergraduate level. A few years down the track, ideas were generated by academics as to what might a Capstone Course include. Indeed, scholars seemed to be struggling with ways to improve students' understanding of their responsibilities towards society, through enhancement of their moral reasoning. Payne (1988) contends that knowledge of the characteristics and limitations of values and ethics-related measures allows business educators to make better selections of possible supplements to traditional instructional methods. While Payne et al. (2002) raise the issue of stakeholders networking and its importance for the successful development and implementation of Capstone Courses.

Providing evidence on the importance of ethics and its inclusion in the accounting curriculum, Armstrong (1993) advocated that ethics be taught both in existing accounting courses and in a separate course in accounting ethics and professionalism. Armstrong (1993) believed that a "sandwich approach" should be used, consisting of a general course in ethics taught elsewhere in the university, followed by a variety of accounting courses in which case studies and homework problems help students to identify ethical issues and reinforce the need for mature ethical reasoning, followed by a Capstone Course in ethics and professionalism taught by the accounting faculty. Armstrong (1993) not only suggested a new method of teaching Capstone, but provided evidence, using James Rest's Defining Issue Test (DIT), in a pre-test/post-test design, indicating that the course could be effective in raising students' levels of moral development beyond what is expected to occur naturally, especially if the students have previously taken one or more courses in ethics. Therefore, a Capstone Course comprising ethics and professionalism could make a difference in our students' lives by exposing them to ethical theories and theories of professionalism. The purpose of such exposure is to enhance their moral development, to enable them to think more critically when confronted by moral dilemmas, and to become thinking participants in the profession they will soon be entering. Shaub (1994) provides evidence which indicates that educators (e.g. accounting educators) can influence the moral reasoning of the profession by recruiting and retaining bright students, particularly women, and by designing ethics education interventions that help students to incorporate more than simply rules when making ethical decisions.

In addition, Bussiere (2005) argues that case studies are a sound means of providing students with a real-world context for business issues, structure analysis and decision-making. Jervis and Hartley (2005) posit that a Capstone Course is a culmination of academic experience that ties together all previous courses in an academic discipline and facilitates the transition to a chosen career. The rationale for their accounting Capstone Course is based on institutional and departmental objectives, as well as accounting education change initiatives highlighting the 
importance of paying close attention to issues such as course content, instructional methods, assignment of faculty, class size, and assessment, providing description of their course requirements, syllabus, topics and readings.

Gorman $(2011,2010)$ outlines a Capstone experience of an operations management major at Dayton University, which involves consulting projects using actual client problems, which allows students to gain valuable experiences through the application of their technical skills in a real environment. Over a period of time, Gorman $(2011,2010)$ collected both quantitative and qualitative data recording students' reactions to the course, through evaluations collected at the time the course was taken, a retrospective of the four-year experience upon graduation, and a survey that captures graduate reflections on the course up to seven years after its completion. Gorman $(2011,2010)$ concludes that despite the inherent risks of offering a Capstone Course based on field work, students find the experience both of tremendous practical value and strong academic rigor.

Proposing an alternative methodology for teaching Capstone Courses like Strategic Management through the use of applied research, Lee (2012) reiterates the main reason behind the introduction of any Capstone Course, no matter what name it is given. Certainly, it is to tie together into one coherent package the various concepts learned throughout the students' business education in disciplines such as accounting, finance, management, marketing, human resources, operations management, and the like, which are often taught using a case study methodology.

\section{Capstone for Postgraduate Courses}

Allard and Staussman (2003) pose the question: how do professional programs in public affairs try to bridge the worlds of classroom and practice? Deriving from the literature, they respond that this is done by introducing experiential learning which can be achieved by including a clinical component in the curriculum, frequently a 'Capstone' experience. They elaborate that the Capstone design integrates knowledge and skills learned throughout the curriculum in a single analytic project or exercise. In public affairs post-graduate classes, Capstones should not only achieve this but also should ease the transition from student to professional by exposing students to the realities of working in a policy research or organizational setting. Some Capstones use project-based assignments that focus on current policy and management challenges faced by actual government or non-profit agencies; other project-based assignments may take the form of consulting relationships with real-world clients. While in nursing and engineering, Aller et al. (2008) highlight the importance of teams and team design which they consider as critical for the success of such a Course. They affirm that the team formation in a Capstone class and projects allow students to experience what the real world will offer them by applying their skills and decision-making tools to solve genuine problems.

While in business schools, there are various approaches to Capstone depending on the particular discipline (e.g. accounting, marketing, finance, economics and management) offering the course. From the accounting perspective, Kohlbeck (2005) discusses the importance of the case study approach which requires financial analysis in order to evaluate a number of judgements involved and resulting in recommendations to management stating. This method has four objectives: to increase students' understanding and exposure to the integration of financial reporting decisions with financial statement analysis that would help students to understand how business decisions impact on reporting; to demonstrate how decisions may be influenced by pressures to manage earnings; to produce desirable financial results, and finally, to raise ethical issues in an accounting setting. Still focusing on individual disciplines (e.g. accounting), Johnson and Halabi (2011) in their research on Capstone Courses, discovered that such courses promote personal and functional skill development in areas such as research, problem-solving, critical thinking, reflection, synthesis, teamwork, communication and professional orientation, which are envisaged to prepare students for their accounting profession and make solid connections with their 
business environment and professional accounting bodies. Describing a post-graduate Capstone accounting class as a basis for building communication skills desired by both accounting practitioners and accounting faculty, Sharifi et al. (2009) recommend that an academic servicelearning (ASL) component be included, indicating that the three most important skills are written communication, oral communication, and analytical/critical thinking. Accounting curricula worldwide are under pressure to develop better skills in these areas as well as to meet assessment and accreditation directives and criteria. The authors designed a communication course utilizing ASL that not only met their objectives but also provided the students with hands-on experiential learning.

Still in the business school, Kachra and Schnietz (2008) discuss the traditional Master of Business Administration (MBA) Capstone strategy course intended to integrate the prior work done in the MBA course. However, Kachra and Schnietz (2008) contend that this course is doing this less and less well in today's high-velocity and complex business environment. The traditional strategy course structures, emphasizing formulation, implementation and the internal/external environments, do relatively well at developing theoretical and applied integration skills but do poorly in developing practical integration skills, the very skills increasingly demanded by employers. Kachra and Schnietz (2008) do not believe that the traditional organization of and pedagogies for the Capstone strategy course develop the level of integrated thinking necessary for managers to make good decisions in today's business environment. They suggest reorganizing the strategy Capstone Course along the levels of managerial decision-making and emphasizing pedagogies that employ rich-enough cases and business simulations to better develop integration skills, particularly practical integration skills, in MBA students.

However, Boehner and O’Neil (2010) go a step further by discussing the education of managers in academic programs such as Executive MBA programs which they feel present a unique challenge to college administrators and faculty. Executive students are more demanding and critical, and value experiential education more than do students in undergraduate or MBA programs. Also, compared to regular MBA students, executive students want to understand management in a more holistic manner. They want to see the connection between subject matter taught by different academic disciplines and understand how experienced managers can sort through the details, see the big picture, and make effective decisions. Over the years, Executive MBA programs have used a variety of innovative pedagogy to introduce students to 'real world' business problems. Methods used include case studies (Harper et al. 2000), simulations, field visits, guest lectures by business executives, and international trips. However, none of these approaches adequately provided the experiential learning desired by executive students.

Describing a pedagogical technique that has been used successfully for more than 35 years in business education, primarily as a Capstone experience in MBA and Executive MBA programs, Rashford and de Figueiredo (2011) argue the case for the live in-class CEO (Chief Executive Officer) intervention method. This method consists of a CEO bringing to the classroom a strategic issue that she or he is currently struggling with and addressing it in real time with a team of students. The technique is most effective when used alongside a strategic framework of the instructor's choice. Moshkovich (2012) contends that Capstone Courses in many programs are used to ensure the convergence of basic knowledge, skills and other ingredients that would adequately prepare the student for the business world. Moshkovich describes two types of Capstone Course: one is a research project on a relevant topic of systems analysis and design, while the second one is a development project. Both forms were found to be appreciated by students while some preference for the development project was demonstrated.

Through an examination of a course history, Mong (2011) tries to answer the question: what learning should occur in an undergraduate Capstone business course? Mong (2011) highlights five learning goals: (1) to integrate students' prior functional learning; (2) to teach students to work within uncertainty; (3) to provide the CEO's perspective on managing companies; (4) to analyze strategic models; and (5) to reinforce each student's functional business skills. Mong (2011) also 
examines a number of learning objectives that have sprung from those goals, highlighting the importance of prioritizing coverage to prepare today's students for future challenges.

The literature cited above indicates that both post- and undergraduate Capstone Courses are intended to enhance the students' abilities to identify a problem, think critically, analyse the situation, and recommend solutions, although each discipline chooses a slightly different approach, method, and means of delivery.

Therefore, and despite the differences between various disciplines and countries, it can be concluded that a Capstone Course could be described as the bridge between the worlds of classroom and that of practice. The proper formation of teams, strategy, academic rigor, servicelearning, fostering of skills such as communication (oral and written), analytical and critical thinking, the live in-class CEOs intervention method, real-world business problems, case studies, simulations, field visits, guest lectures by business executives, and international trips, are some of the methods that can be used to develop and implement a successful Capstone Course. However, more recently, and in addition to the basic business and communication skills, businesses are eager to see graduates taking a more holistic approach to understanding management that includes a consideration of its three components of people, planet and profit. These components are evident in some Capstone Courses, but there is still more work to be done in this regard.

Certainly, when considering the literature dealing with the development and teaching of a Capstone Course in different disciplines, there are diverse ideas, with various outcomes and various specifications. At the author's university, numerous issues need to be addressed and it is essential that any Capstone Course that is developed allows the students to acquire desirable graduate attributes, and is aligned with the mission, vision and strategy of the school and the university. In the following section, the author shares her experience and suggestions subsequent to being given the task of developing a Capstone Course for her faculty in an Australian university. For fluency, and to emphasize the personal nature of the experience, the first person pronoun will be used.

\section{My Contribution to Capstone Course}

\section{Methodology}

Prior to beginning the development of a Capstone Course, I read my job description that provided me with pointers about requirements and priorities for the newly designed course. Guided by the contents of this job description, I met with key personnel at the faculty and university levels, simultaneously conducting local and international research and collecting statistical data from relevant literature and others experiences in the field. The literature review conducted during this period allowed me to sharpen my understanding and to familiarise myself with what had already been achieved locally and internationally with regards to Capstone Courses. This allowed me to determine the areas where I could add value by contributing some original thinking and perspective, and an innovative way of developing and delivering a Capstone Course. It is worthwhile to acknowledge here the immense assistance that I received from various colleagues within the faculty, the university and outside the university, which assisted me to design and structure my vision for this Capstone Course.

\section{Vision}

My vision for the undergraduate Capstone Course was informed by the fact that at our business school there are several majors that are offered by six schools (i.e. Management, Marketing, Information Systems, Economics and Finance, Business Law and Accounting). In addition and within each of these schools, there are other disciplines. For example, in the School of Management, we have the Management, Human Resources, and International Business disciplines with some 2,000 students per semester/trimester from within Australia and from partner campuses in South East Asia. All these variables contributed to the complexity of the design. 
The vision was based on the fact that students graduating from our business school might take one of two directions. The first is research, joining a post-graduate programme within or outside the university, while the second is careers. Thus, in my vision I considered different methods that I could apply to the design of a Capstone Course that would assist students to acquire or improve generic skills, give them the necessary experience to enable them to cope with the pressures of lifelong learning in the workplace, ensure their smooth transition to post-graduate studies in business or to the workforce. In other words, the course would be one that prepares graduating students for the challenges of a career in research or industry.

The task was made more challenging and complex because of the number of different schools, different disciplines within these schools, different locations (onshore and offshore) online, and the huge number of students during each study period. Regardless of student numbers, location and mode of course delivery, students need to acquire and refine their skills in team work, analytical thinking, communication, research, writing, and oral presentation, to name a few. Above all, it was essential to ensure that through this Capstone Course the students will actually 'CAP' their studies, and be able to demonstrate all the university's desirable graduate attributes such as the ability to apply their discipline knowledge, enhanced critical thinking, demonstrating effective communication, running a successful collaborative team, and exhibiting sociocultural and ethical skills.

The mandate given to me by the faculty office was to extend the old concept of concentrating on the disciplines separately (e.g. marketing, management, accounting, economic and finance, law, and information systems) by allowing the students to gain a holistic idea of business, thereby acquiring the necessary knowledge enabling them to think analytically and creatively. Indeed, a community and society are enriched if their future leaders can apply their thinking to major issues such as the assurance of a sustainable environment, sustainable economy and overall sustainable society.

This vision is both innovative and difficult to realize. Hence, my next question concerned how best to develop a Capstone Course that would successfully fulfil its intended goals. Initially, I sought to establish a stronger co-operation with university management, the faculty, different schools, different disciplines and different locations. Also, I aimed to establish and maintain strong spirit of co-operation and collaboration with the university's Information Systems staff, the alumni and industry. It was essential that this be a dynamic partnership from the outset. Thus, there was a need to establish a specialised and capable Capstone team led by me, the Unit Coordinator (i.e. the course coordinator), that would be responsible for establishing and maintaining relationships with different stakeholders, for the purpose of developing teaching material and assessments, and most importantly, enhancing the research capabilities that lead to publications by both faculty members and students. Also needed was a serious consideration of the training of lecturers in e-learning methods, and, liaising with industry (locally and overseas) to prepare for problems that needed to be handed to the students in their groups at the beginning of the study period and throughout the semester, and in a way imitating the 'real world'. It was hoped that industry would provide several 'surprises' to the students in order to enhance their abilities to deal with the uncertainty that is the hallmark of our contemporary world. In this respect, I recognised that it was essential that the problems presented by industry, or the service(s) required, were within the capabilities of the students. Otherwise, it was highly probable that students would be discouraged and abandon the course or, worse, give up their university studies entirely. This unfortunate outcome was documented by Wright (2010) who reported on a Capstone Course for programming that resulted in the loss of student interest in artificial sciences which was blamed in part on the impression that they require extraordinary programming skills to succeed in the real world. Though this might be considered a problem-based tool of learning, it was more a service-based learning activity, in which students would be providing a service to the industry without any remuneration. This type of service should be provided at a professional level, whereas the Capstone students will be given a mentor who would be practice-based in addition to their lecturer/tutor and Unit Coordinator. 
It is crucial that initial projects be delivered on time and to a high standard in order to establish in the market the good reputation of the university and its students. It is important that industry perceives the students and faculty of the university in a positive light, providing a service and being capable of sensing, finding, and solving problems, suggesting solutions and making recommendations to industry for better and more sustainable ways of doing business. When this is achieved, it is anticipated that applications would be received from organizations seeking assistance for the development of plans for their projects, or seeking solutions or recommendations for their problem. Whilst this would enhance the faculty, schools and university's reputation, it will add to the responsibilities of those involved in the Capstone Course, whereas there is a need to screen these projects for their suitability and alignment with the graduate attributes and the course outcomes. This was anticipated to be a future concern and one that would be dealt with as the need arose.

The idea was presented to the management, it was welcomed, and suggestions were given on how the support in the form of committees and more staff dedicated to this project could be provided.

\section{Challenges and Limitations}

But the vision here simply means 'change' and when it comes to change (Jackson 2010) highlights three areas: (1) political, (2) collegial, and, (3) individual. With regards to political, the individual responsible for developing such an important course (i.e. the Unit Coordinator 'UC') needs to maintain the necessary authority and be in a position to influence senior management within the university, faculty, schools and disciplines (locally and overseas). As for the collegial area, this UC must be able to influence the university's teaching and learning committees that usually make/approve educational policies. Thirdly, the individual, in this case the UC, needs to be in a position to present ideas and be involved in the adaptation of the practices or introduction of new practices at the discipline, school, faculty and university levels. Several other challenges were also identified including the high number of students (i.e. approximately 2,000 students per study period), professional relationships with industry, the offshore component of the students in the faculty, the involvement of sessional/contract staff, peer evaluation, alumni, and group and team issues. In addition, there was a need to consider the limitation of time since only twelve weeks were available during which all outcomes had to be achieved to a high standard.

Another challenge was posed: while the students in our faculty would be introduced to sustainability and relevant issues in their first year of study, some might be required to undertake a 'business ethics' course in their third year, depending on their major, and not all students would have the same level of moral maturity. This poses the question as to whether there is a need to educate those students in the basics of the different ethical perspectives and theories, prior to engaging them in discussions about ethical issues. This might be a waste of time to others who have already taken the course or would be taking the course simultaneously with the Capstone Course. Thus, there was a request to the faculty to make ethical and cultural education a requirement throughout the degree, an issue that is currently being addressed by the faculty.

Further, due to the risks involved in developing and running a course which has several stakeholders both within and outside the university, I suggested that the first step be the formation of a committee responsible for the development of course content comprising a combination of problem-based and service-based learning tools. However, the material would not be used in all campuses at once, but offered as a pilot scheme for one location during one of the teaching periods. A pilot location would assist all team members to identify any problems that might arise. These can be dealt with more easily when the number of stakeholders involved is small, rather than delivering the new material to all stakeholders at once, and risking ultimate catastrophe. 


\section{Conceptual Model for the design of a Capstone Course}

Therefore, it was concluded that for this Capstone Course task to be achieved, there is a need to establish and maintain co-operation between university, faculty, schools, their disciplines, and both local and overseas industries. This co-operation needs to be at the highest level in order to provide a Capstone experience for our students that would give them the necessary knowledge of theories and content coupled with the opportunity to apply those theories in practice, thereby enhancing and developing students' communication and professional skills imbued with mature moral reasoning and capacity for reflection.

This is depicted in Figure 1 below.

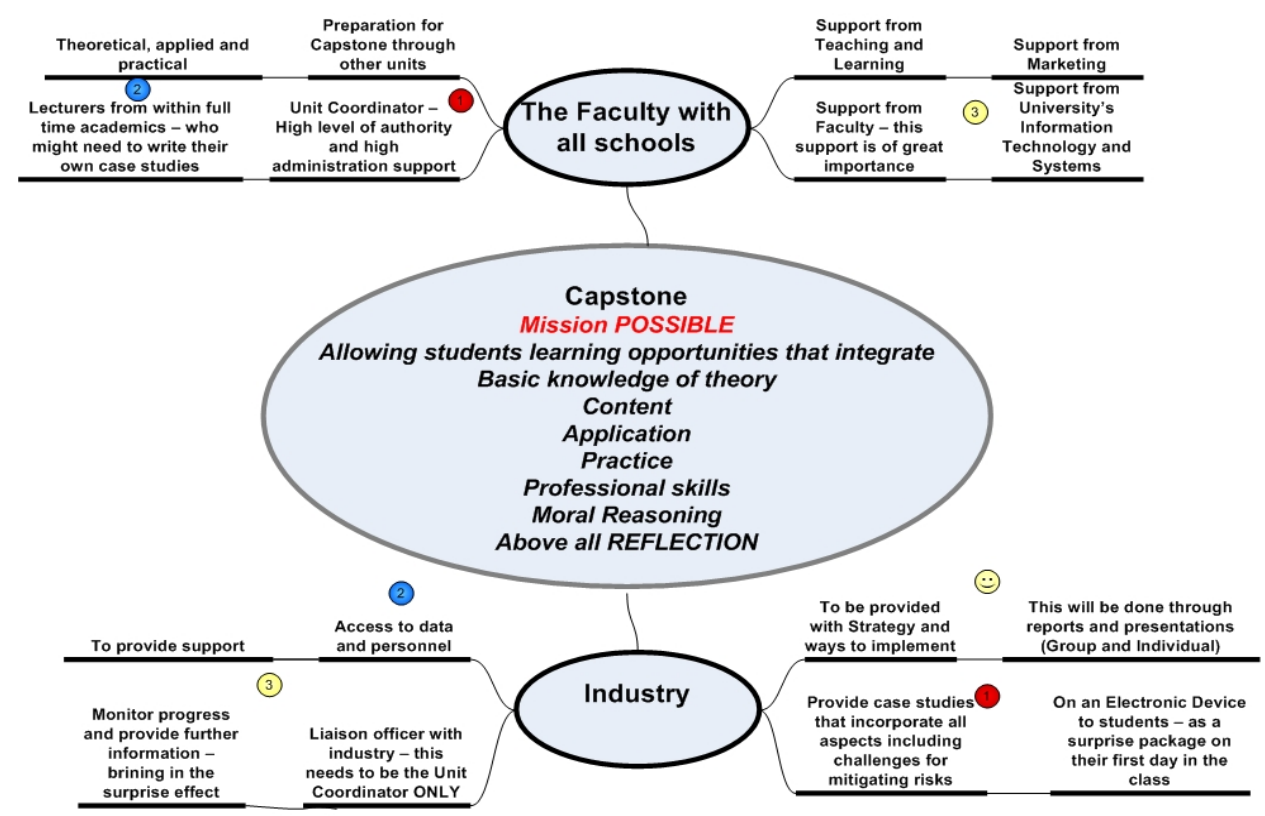

Figure 1: Conceptualization of the stages needed for the relationship development between different stakeholders for the design of a Capstone Course (Theodora Issa).

Whilst this had the support of several faculty members and schools, nevertheless, the requested committee was never established. It was infeasible that such a project could be successfully implemented by only one individual; hence, other methods and tools needed to be used in order to design and deliver the Capstone Course, but due to the space limitations of this paper, these options will not be elaborated upon here.

\section{Conclusion}

This paper reported on the great opportunities and the immense challenges that could be faced by academics involved in the development and delivery of a Capstone Course. This paper provided, and through the extensive literature review, different methods or frameworks of delivery of a Capstone Course in diverse disciplines, at various faculties and at different levels. Further, this paper shared with the readers a 'theoretical' vision rather than a 'practical' implementation of how a business Capstone Course could be developed and presented to inter-disciplinary business 
students in Australia. Its limitations were identified and suggestions were offered regarding how best to develop such a course and ensure that its goals are achieved.

Other methods and visions have been developed since then, and those will be the subject of other papers in the future. Certainly, further research can be conducted on each of these visions. This research contributes to the literature on higher education and the linkages between university education and the capabilities of the students they graduate, thereby facilitating a successful transition from university to work. Pilot sites need to be identified, their visions examined, and only the best chosen for the curriculum. This would be a service that the academics, and those involved in higher education can extend to the students, their main stakeholders, their community and society, expressing their social responsibility through a sustainable higher education curriculum. 


\section{REFERENCES}

Allard, S. W. \& Straussman, J. D. 2003. 'Managing Intensive Student Consulting Capstone Projects: The Maxwell School Experience'. Journal of Policy Analysis and Management, 22:4, 689-701.

Aller, B. M., Lyth, D. M. \& Mallak, L. A. 2008. 'Capstone Project Team Formation: Mingling Increases Performance and Motivation'. Decision Sciences Journal of Innovative Education, 6:2, 503-07.

Armstrong, M. B. 1993. 'Ethics and Professionalism in Accounting Education: A Sample Course'. Journal of Accounting Education, 11, 77-92.

Aurand, T. W. \& Wakefield, S. A. 2006. 'Meeting AACSB Assessment requirements through peer evaluations and rankings in a Capstone Marketing class'. Marketing Education Review, $16: 1,40-46$.

Boehner, R. \& O'Neil, B. 2010. 'Executive MBA Capstone Projects at RIT Saunders College of Business An Enriching Experience for All'. Journal of Executive Education, 9:1, 79-111.

Brabston, M. 2005. 'Teaching Ethics in the MIS Strategy/Capstone Course'. Paper presented at AIS SIG-ED IAIM Conference.

Bussiere, D. 2005. 'Forensic Marketing: The Use of the Historical Method in a Capstone Marketing Course'. Journal of Marketing Education, 27:1, 61-67.

Cohen, S., Eimicke, W. \& Ukeles, J. 1995. 'Teaching the craft of policy and management analysis: the workshop sequence of Columbia University's graduate program in public policy and administration'. Journal of Policy Analysis and Management, 14, 606-26.

Crittenden, V. L. \& Crittenden, W. F. 2006. 'The Undergraduate Capstone Marketing Course: Objectives, Content, and Pedagogy'. Journal of Advancement of Marketing Education, 8:Summer.

Elkington, J. 1997. 'Cannibals with forks: The triple bottom line of 21st century business'. Capstone.

Francisco, W., Noland, T. G. \& Sinclair, D. 2008. 'AACSB Accreditation: Symbol of Excellene or March Toward Mediocrity?' Journal of College Teaching and Learning, 5:5, 25-30.

Giacalone, R. A., Jurkiewicz, C. L. \& Knouse, S. B. 2003. 'A Capstone Project in Business Ethics: Building an Ethics Training Program'. Journal of Management Education, 27:5, 590-607.

Gorman, M. F. 2010. 'The University of Dayton Operations Management Capstone Course: Undergraduate Student Field consulting Applies Theory to Practice'. Interfaces, 40:6, 432-43.

Gorman, M. F. 2011. 'Student Reactions to the Field consulting Capstone Course in Operations Management at the University of Dayton'. Interfaces, 41:6, 564-77.

Harper, J. S., Lamb, S. W. \& Buffington, J. R. 2000. 'Effective Use of Case Studies in the MIS Capstone Course through Semi-Formal Collaborative Teaching'. Journal of Information Systems Education, 19:4, 411-18.

Heuer, M. 2010. 'Foundations and Capstone: core values and Hot Topics; Ethics-LX; skyTech; and The Green Business Laboratory: simulations for Sustainability Education'. Academy of Management Learning and Education, Book and Resource Review:September, 556-61.

Jauch, L. R., Snodgrass, C. R. \& Szewczak, E. J. 1988. 'Capstone Renaissance = Simulation + Interaction + DSS'. Developments in Business Simulation \& Experiential Exercises, 15.

Jervis, K. J. \& Hartley, C. A. 2005. 'Learning to Design and Teach an Accounting Capstone'. Issues in Accounting Education, 20:4, 311-39.

Kachra, A. \& Schnietz, K. 2008. 'The Capstone Strategy Course: What Might Real Integration Look Like?' Journal of Management Education, 32:4, 476-508.

Kohlbeck, M. 2005. 'Reporting Earnings at Summer Technology - A Capstone Case Involving Intermediate Accounting Topics’. Issues in Accounting Education, 20:2, 195-212. 
Lee, M. A. 2012. 'Teaching Strategic Management: Moving from Case Analysis to Applied Research'. Review of Business Research, 12:2, 69-77.

Matos, V. \& Grasser, R. 2006. 'Using Reengineering as an Integrating Capstone Experience'. Journal of Information Systems Education, 18:1, 85-101.

Mills, R. J., Hauser, K. \& Pratt, J. A. 2008. 'A Software Development Capstone Course and Project for CIS Majors'. Journal of Computer Information Systems, Summer, 1-14.

Mong, D. 2011. 'Goals and Learning Objectives for Capstone Business Courses'. Journal of the Northeastern Association of Business, Economics and Technology, Fall, 21-29.

Moshkovich, H. M. 2012. 'Development Project VS. Research Project in an MIS Capstone Course: Student Perceptions'. Review of Business Research - International Academy of Business and Economics (IABE), 12:2, 140-44.

Murray, M., Perez, J. \& Guimaraes, M. 2008. 'A Model for Using a Capstone Experience as One Method of Assessmentof an Information Systems Degree Program'. Journal of Information Systems Education, 19:2, 197-208.

Nickerson, J., Yen, C. J. \& Mahoney, J. T. 2012. 'Exploring the Problem-Finding and ProblemSolving Approach for Designing Organizations'. Academy of Management Perspectives, February:http://dx.doi.org/10.5465/amp.2011.0106, 52-72.

Payne, S. L., Whitfield, J. M. \& Flynn, J. A. 2002. 'Assessing the Business Capstone Course Through a Method Based on the SOTL and the Stakeholder Process'. Journal of Education for Business, November/December, 69-74.

Ras, E., Carbon, R., Decker, B. \& Rech, J. 2007. 'Experience Management Wikis for Reflective Practice in Software Capstone Projects'. IEEE Transactions on Antennas and Education, 50:4, 312-20.

Rashford, N. S. \& de Figueiredo, J. N. 2011. 'the Live In-Class CEO Intervention: A Capstone Experiential Technique for Leadership Development'. Journal of Management Education, 35:5, 620-47.

Razaki, K. A. \& Collier, E. 2011. 'Ethics: the soul of a business Capstone course'. Journal of Academic and Business Ethics, 1-13.

Razaki, K. A., Koprowski, W., Alonzi, P. \& Irons, R. 2010. 'Centering the business Capstone course on the banking crisis: concrete integrated pedagogy'. Research in Higher Education Journal.

Reid, M., Brown, S. \& Tabibzadeh, K. 2012. 'Capstone Teaching Models: Combining Simulation, Analytical Intuitive Learning Processes, history and Effectiveness'. Journal of Business Education, 87, 178-84.

Shaub, M. K. 1994. 'An Analysis of the Association of Traditional Demographic Variables with the Moral Reasoning of Auditing Students and Auditors'. Journal of Accounting Education, 12:1, 1-26.

Starr-Glass, D. 2010. 'Reconsidering the International Business Capstone: Capping, Bridging, or Both?' Journal of Teaching in International Business, 21, 329-45.

Strauss, J. 2011. 'Marketing Capstone Models The Apprentice Television Show With ClientSponsored Projects'. Journal of Marketing Education, 33:3, 312-25.

Wei, K. \& Burley, D. L. 2006. 'Implementing Service-learning to the Information Systems and Technology Management Program: A study of an Undergraduate Capstone Course'. Journal of Information Systems Education, 18:1, 125-36.

Whitla, P. 2011. 'Integrating Ethics into International Business Teaching: Challenges and Methologies in the Greater China Context'. Journal of Teaching in International Business, 22, 168-84.

Wiechowski, L. S. 2010. 'Developing And Implementing An Undergraduate Finance Capstone Course For Both Onground And Online Course Deliverty'. American Journal of Business Education, 3:12, 87-93. 
Wright, K. 2010. 'Capstone Programming Courses Considered Harmful'. Communications of the ACM, 63:4, 124-27.

\section{ABOUT THE AUTHOR}

Dr. Theodora Issa: Dr Theodora Issa is a senior lecturer at the Faculty Office of Curtin Business School, Curtin University, at Secondment at the School of Management, Australia. Theodora's $\mathrm{PhD}$ thesis was on ethical mindsets, spirituality, and aesthetics and was the recipient of the 2010 EFMD/Emerald Outstanding Doctoral research award. Theodora holds a Master of Business Administration, a Master of Electronic Commerce and a Master of Management Research. Theodora's research interests include teaching, online teaching and learning, ethical mindsets, ethical climate, misconduct resistance and prevention of corruption, spirituality, aesthetic judgment, sustainable business development and ethical strategies, which ignited her interest in Green IT and cloud-computing. Theodora has participated in several conferences on ethics, teaching and learning, sustainability, and has been the recipient of 'best paper wars in 2009, 2010, and 2011. Theodora has published books, book chapters, in several peer-reviewed journals, and she is a member of editorial committees, and a member of different governing bodies. 
The International Journal of Learning in Higher Education is one of ten thematically focused journals in the collection of journals that support The Learner knowledge community - its journals, book series, conference and online community. It is a section of The International Journal of Learning.

The journal offers studies of learning at college and university levels, including teacher education.

As well as papers of a traditional scholarly type, this journal invites presentations of practice-including documentation of higher education practices and exegeses of the effects of those practices.

The International Journal of Learning in Higher Education is a peer-reviewed scholarly journal.

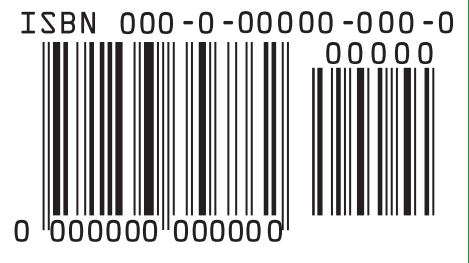

